\title{
Upregulation of hypothalamic nitric oxide synthase gene expression in streptozotocin-induced diabetic rats
}

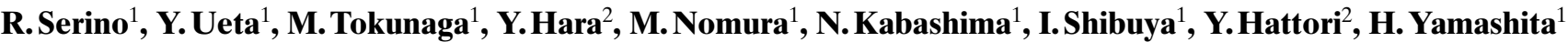 \\ ${ }^{1}$ Department of Physiology, School of Medicine, University of Occupational and Environmental Health, Kitakyushu, Japan \\ ${ }^{2}$ Department of Foods and Human Nutrition, Faculty of Human Life Sciences, Notre Dame Seishin University, Okayama, Japan
}

\begin{abstract}
Summary Plasma arginine vasopressin (AVP) is known to be elevated in patients with uncontrolled insulin-dependent diabetes mellitus who have plasma hyperosmolality with hyperglycaemia. Although osmotic stimuli cause an increase in nitric oxide synthase (NOS) activity as well as synthesis of AVP and oxytocin in the paraventricular (PVN) and supraoptic nuclei (SON), it is not known whether NOS activity in the hypothalamus changes in the diabetic patients who have plasma hyperosmolality with hyperglycaemia caused by insulin deficiency. Expression of the neuronal (n) NOS gene in the PVN and SON in streptozotocin (STZ)-induced diabetic rats was investigated by using in situ hybridization histochemistry and NADPH-diaphorase histochemical staining. Four weeks after intraperitoneal (i.p.) administration of STZ, male Wistar rats developed hyperglycaemia and plasma hyperosmolality. The expression of nNOS gene and NADPH-diaphorase staining in the PVN and SON remarkably increased in STZ-induced
\end{abstract}

diabetic rats compared to control rats. Three weeks after administration of STZ, the diabetic rats were subcutaneously treated with insulin for 1 week, which resulted in significant suppression of the induction of nNOS, AVP and oxytocin gene expression in the PVN and SON. Furthermore, the induction of nNOS gene expression in the PVN and SON was suppressed in STZ-induced diabetic rats treated with phlorizin and diet to normalize hyperglycaemia without insulin treatment. These results suggest that upregulation of nNOS gene expression as well as AVP and oxytocin gene expression in the PVN and SON in STZ-induced diabetic rats may be associated with hyperglycaemia and plamsa hyperosmolality. [Diabetologia (1998) 41: 640-648]

Keywords Histochemistry, hyperosmolality, mRNA, nitric oxide, oxytocin, paraventricular nucleus, supraoptic nucleus, vasopressin.
The peripheral administration of streptozotocin (STZ) causes marked hyperglycaemia, plasma hyperosmolality, hypoinsulinaemia, hyperphagia and poly-

Received: 16 September 1997 and in revised form: 9 February 1998

Corresponding author: Dr. H. Yamashita, Department of Physiology, School of Medicine, University of Occupational and Environmental Health, 1-1 Iseigaoka, Yahatanishi-ku, Kitakyushu 807-8555, Japan

Abbreviations: AVP, arginine vasopressin; NOS, nitric oxide synthase; PVN, paraventricular nucleus; SON, supraoptic nucleus; STZ, streptozotocin; nNOS, neuronal NOS; NADPH, nicotinamide adenine dinucleotide phosphate; NO, nitric oxide; PBS, phosphate buffered saline; NPY, neuropeptide Y. dipsia. In STZ-induced diabetic animals, insulin treatment reverses these symptoms. Several studies have demonstrated that insulin deficiency induced diabetes causes alteration of hypothalamic transmitters and the gene expressions of neuropeptides [1-7]. These studies suggest that the alteration of monoamine and neuropeptides in the hypothalamus may play a role in the multiple behavioural and hormonal abnormalities in STZ-induced diabetic rats.

Recent studies have demonstrated that nitric oxide (NO) may be associated with various functions of the central nervous system, including feeding [8-12] and drinking behaviour [13,14]. It has been demonstrated that both systemic administration of a competitive antagonist of NO synthase (NOS) and 
central administration of an NOS inhibitor inhibited food intake in food deprived mice and rats [8-10], and moreover systemic administration of an NOS inhibitor inhibited food intake in chickens [11] and obese Zucker rats [12]. Central administration of $L$ arginine, the precursor amino acid of NO, inhibited drinking in water-deprived rats [13, 14]. Several studies have demonstrated that expression of neuronal NO synthase (nNOS) gene in the hypothalamic paraventricular (PVN) and supraoptic nuclei (SON) is increased by osmotic stimuli such as dehydration [15, $16]$ and salt loading $[17,18]$. The magnocellular neurosecretory cells in the PVN and SON synthesize arginine vasopressin (AVP) and oxytocin and release them into the systemic cirulation from their axon terminals located in the posterior pituitary. Some studies have demonstrated that hypothalamic NO inhibits release of AVP [17, 19, 20] and central NO tonically inhibits basal release of AVP and oxytocin [21, 22]. Thus, NO may play an important role in the modulation of secretion of AVP and oxytocin in the hypothalamo-neurohypophysial system $[17,19,23]$.

Plasma AVP is known to be elevated in patients with uncontrolled insulin-dependent diabetes who have plasma hyperosmolality with hyperglycaemia [24]. The synthesis of hypothalamic AVP and oxytocin in diabetic rats was also seen to be increased [6]. Although NOS activity as well as synthesis of AVP and oxytocin in the hypothalamus is increased by plasma hyperosmolality under physiological conditions, it remains unknown whether NOS activity is increased or not in the diabetic rats that have plasma hyperosmolality with hyperglycaemia caused by insulin deficiency.

In the present study, the expression of nNOS gene in the PVN and SON was examined using in situ hybridization histochemistry in STZ-induced diabetic rats. Nicotinamide adenine dinucleotide phosphate (NADPH)-diaphorase histochemistry was used to confirm the change in NOS enzyme activity in the PNV and SON. Furthermore, the effects of insulin treatment of diabetic rats on nNOS gene expression in the PVN and SON were examined. In addition, phlorizin (a continuous inhibitor of renal tubular reabsorption of glucose)-treatment and diet were used to normalize the plasma glucose level in STZ-induced diabetic rats. The expression of AVP and oxytocin genes in the PVN and SON were simultaneously examined as inner controls because they were expected to be upregulated in the diabetic rats.

\section{Materials and methods}

Animals. Adult male Wistar rats, weighing between 80 and $150 \mathrm{~g}$, were used in all experiments from the start. They were housed three per plastic cage in an air-conditioned room (23-25 $\left.{ }^{\circ} \mathrm{C}\right)$ under a 12-h light (07.00-19.00 hours) / 12-h dark (19.00-07.00 hours) cycle.
Experimental procedure. A solution $(1 \mathrm{ml} / \mathrm{kg})$ of $0.9 \% \mathrm{NaCl}$ containing STZ $(80 \mathrm{mg} / \mathrm{ml})$ was administered once intraperitoneally (i.p.) to rats fasted for $24 \mathrm{~h}(n=20)$. The same volume of $0.9 \% \mathrm{NaCl}$ was administered i. p. to control rats $(n=6)$. These solutions were freshly dissolved and shielded from the light. At 2 days and 3 weeks after i.p. administration of STZ, the plasma concentration of glucose was measured using a glucosensor (Glutest E; Sanwa Co. Ltd., Nagoya, Japan). Rats that developed hyperglycaemia $(>16.6 \mathrm{mmol} / \mathrm{l})$ were chosen as typical diabetic rats. These diabetic rats were divided into two groups: one group was given insulin (10-12 IU/rat, Humulin N; Eli Lilly, Kobe, Japan) s. c. once a day at 18.00 hours for 1 week and the other group was given $0.9 \% \mathrm{NaCl}$ s.c. at the same time. The units of insulin administered were decided by a preliminary study that was monitoring the daily plasma glucose concentration. All rats had ad libitum access to tap water. STZ-treated animals and the corresponding controls were always handled in the same way and were killed by decapitation on the same day, 4 weeks after STZ administration. Blood and brain tissue samples were collected and analysed simultaneously. All procedures were in accordance with the Japanese Physiological Society's guidelines for animal care. This experiment was repeated twice independently. The first experiments were undertaken for the analysis of nNOS and AVP transcripts. The second experiments were undertaken for the analysis of nNOS and oxytocin transcripts. In addition, to examine the effects of insulin on expression of the nNOS gene in the PVN and SON in normal rats, insulin (0.4 IU/rat) was administered s.c. at 09.00 hours and rats were decapitated the next day at 09.00 hours. These rats were allowed free access to water but deprived of food for 1 day.

Furthermore, to normalize the glucose levels in STZ-induced diabetic rats, phlorizin (Sigma, St.Louis, Mo., USA) $\left(0.4 \mathrm{~g} \cdot \mathrm{kg}\right.$ body weight ${ }^{-1} \cdot$ day $\left.^{-1}\right) ;$ made up as a $25 \%$ solution in propylene glycol, was administered s. c. every $8 \mathrm{~h}$ for 12 days in STZ-induced diabetic rats, according to the published protocol [25]. In Group I phlorizin $\left(0.4 \mathrm{~kg} \cdot \mathrm{kg}\right.$ body weight ${ }^{-1} \cdot$ day $\left.^{-1}\right)$ was s.c. administered every $8 \mathrm{~h}$ for 12 days in normal rats $(n=6)$. In these phlorizin-treated rats food was restricted (approximately $25 \mathrm{~g}$ of pelleted food/rat) with free access to water for one and one half days before killing. Control rats usually ate a similar volume of the pelleted food for 1 day. In Group II food was restricted (approximately $25 \mathrm{~g}$ pelleted food/rat) for one and one half days before killing in normal rats $(n=6)$. In Group III were STZ-induced diabetic rats $(n=7)$. In Group IV phlorizin $\left(0.4 \mathrm{~g} \cdot \mathrm{kg}\right.$ body weight ${ }^{-1} \cdot$ day $\left.^{-1}\right)$ was administered s. c. every $8 \mathrm{~h}$ for 12 days, and food was restricted (approximately $25 \mathrm{~g}$ pelleted food/rat) with free access to water for one and one half days before killing in STZ-induced diabetic rats $(n=5)$. All groups (control and Group I-IV) were decapitated at $09.00-10.30$ hours of the same day.

Measurement of glucose, sodium, total protein and osmolality in plasma. Plasma concentrations of glucose, sodium and total protein (TP) were measured by conventional methods. The osmolality of plasma was measured using an Osmotic Pressure AUTO \& STAT (OM-6030; Kyoto Daiichi Pure Chemicals Co. Ltd., Kyoto, Japan).

In situ hybridization histochemistry for $n N O S, A V P$ and $O X T$ $m R N A$. In situ hybridization histochemistry was performed on frozen $12 \mu \mathrm{m}$-thick coronal brain sections cut by cryostat at $-20^{\circ} \mathrm{C}$, thawed and mounted onto gelatin/chrome alumcoated slides that were kept at $-80^{\circ} \mathrm{C}$ until used. The PVN and SON were localized by referring to the atlas 'The rat brain in stereotoxic coordinates' (2nd ed.) by Paxinos and Watson. The PVN and SON of four sections, eight sites per rat were 
used to measure the density of autoradiography. The slides were warmed to room temperature and allowed to dry for $10 \mathrm{~min}$, then fixed in $4 \%$ formaldehyde in phosphate buffered saline (PBS) for $5 \mathrm{~min}$, washed twice in PBS, and incubated in $0.9 \% \mathrm{NaCl}$ containing $0.25 \%$ acetic anhydride (vol/vol) and $0.1 \mathrm{~mol} / \mathrm{l}$ triethanolamine at room temperature for $10 \mathrm{~min}$. The sections were then dehydrated through $70 \%$ (1 min), $80 \%$ (1 $\mathrm{min}), 95 \%(2 \mathrm{~min})$ and $100 \%$ (1 min) ethanol and delipidated in $100 \%$ chloroform for $5 \mathrm{~min}$. The slides were then partially rehydrated in $100 \%$ ( $1 \mathrm{~min}$ ) followed by $95 \%$ (1 min) ethanol and allowed to dry briefly in air. Hybridization was performed at $37^{\circ} \mathrm{C}$ overnight in $45 \mu \mathrm{l}$ of buffer consisting of $50 \%$ formamide and $4 \times \mathrm{SSC}(1 \times \mathrm{SSC}=150 \mathrm{mmol} / \mathrm{l} \mathrm{NaCl}$, $15 \mathrm{mmol} / \mathrm{l}$ sodium citrate) containing $500 \mu \mathrm{g} / \mathrm{ml}$ sheared salmon sperm DNA (Sigma, St.Louis, Mo., USA), $250 \mu \mathrm{g} / \mathrm{ml}$ baker's yeast total RNA (Boehringer Mannheim $\mathrm{GmbH}$, Mannheim, Germany), $1 \times$ Denhardt's solution and $10 \%$ dextran sulfate (500000 MWt, Sigma), under a Nescofilm (Bando Chemical IMD Ltd., Osaka, Japan) coverslip. The probes used were ${ }^{35} \mathrm{~S} 3$ ' end-labelled deoxyoligonucleotide complementary to transcripts coding for nNOS (complementary to bases 796-840 of rat nNOS nucleotides), AVP (complementary to bases 1843-1868 of rat AVP nucleotides) and oxytocin (complementary to bases $912-941$ of rat oxytocin nucleotides). A total of $1 \times 10^{6} \mathrm{cpm} / \mathrm{slide}$ for nNOS transcripts was used. Total of $3 \times 10^{5} \mathrm{cpm} /$ slide for AVP and oxytocin transcripts was used. After hybridization, the sections were washed for $1 \mathrm{~h}$ in four changes of $1 \times \mathrm{SSC}$ at $55^{\circ} \mathrm{C}$ and for a further $1 \mathrm{~h}$ in two changes of $1 \times \mathrm{SSC}$ at room temperature. All independent experimental sections were treated simultaneously to minimize the effects of variation in hybridization and wash stringency. Hybridized sections of the PVN and SON were apposed to autoradiography film (Hyperfilm, Amersham, Bucks, UK) for 7-14 days for nNOS transcripts and $8 \mathrm{~h}$ for AVP and oxytocin transcripts. The resulting images were analysed by computerized densitometry using an MCID imaging analyzer (Imaging Research Inc., Ontario, Canada). The mean optical density of autoradiographs was measured by comparison with simultaneously exposed $\left[{ }^{14} \mathrm{C}\right]$ micro-scale (Amersham, Bucks, UK). Slides hybridized to the nNOS probe were dipped in nuclear emulsion (K5; Ilford, Cheshire, UK) and further exposed for 28 days.

NADPH-diaphorase histochemistry was performed as follows; STZ-induced diabetic rats $(n=3)$ and control rats $(n=3)$ were deeply anaesthetized by i.p. administration of pentobarbital sodium $(50 \mathrm{mg} / \mathrm{kg}$ body weight). They were perfused transcardially with $0.9 \% \mathrm{NaCl}$ containing heparin $(1000 \mathrm{U} / \mathrm{l})$ followed by $4 \%$ paraformaldehyde in $0.1 \mathrm{~mol} / 1$ phosphate buffer ( $\mathrm{pH}$ 7.4). The brain was removed and postfixed with $4 \%$ paraformaldehyde in $0.1 \mathrm{~mol} / \mathrm{l}$ phosphate buffer $(\mathrm{pH} 7.4)$ for $10-12 \mathrm{~h}$ at $4{ }^{\circ} \mathrm{C}$. Tissue samples were then cryoprotected in $10 \%$ sucrose in $0.1 \mathrm{~mol} / \mathrm{l}$ phosphate buffer $(\mathrm{pH} \mathrm{7.4})$ for $24 \mathrm{~h}$ at $4{ }^{\circ} \mathrm{C}$. Serial sections, $50 \mu \mathrm{m}$, were cut using a microtome. The sections were rinsed twice with $0.1 \mathrm{~mol} / \mathrm{l}$ phosphate buffer ( $\mathrm{pH} 7.4$ ) and washed in $0.1 \mathrm{~mol} / 1$ Tris buffer ( $\mathrm{pH}$ 7.6) containing $0.3 \%$ Triton $\mathrm{X}-100$. The free-floating sections were then incubated in $0.1 \mathrm{~mol} / \mathrm{l}$ Tris buffer $(\mathrm{pH} 7.6)$ containing $0.3 \%$ Triton $\mathrm{X}-100,0.2 \mathrm{mg} / \mathrm{ml}$ nitroblue tetrazolium and $1 \mathrm{mg} / \mathrm{ml}$ $\mathrm{NADPH}$ for $40 \mathrm{~min}$ at $37^{\circ} \mathrm{C}$. To stop the reaction, the sections were transferred to $10 \%$ formaldehyde in $0.1 \mathrm{~mol} / \mathrm{l}$ phosphate buffer $(\mathrm{pH} 7.4)$ and rinsed twice with $0.1 \mathrm{~mol} / \mathrm{l}$ phosphate buffer ( $\mathrm{pH}$ 7.4). The sections were mounted onto slides coated with gelatin, air dried, dehydrated in $100 \%$ ethanol, cleared with xylene and covered with a coverslip.

Statistical analysis. All data are presented as mean \pm SEM. The changes in plasma glucose, osmolality and electrolytes after
Table 1. Plasma glucose, sodium, total protein and osmolality in plasma after 4 weeks of streptozotocin and insulin treatment

\begin{tabular}{lrrr}
\hline & Control rats & Diabetic rats & \multicolumn{1}{c}{$\begin{array}{l}\text { Insulin } \\
\text { treatment }\end{array}$} \\
\hline $\begin{array}{l}\text { Plasma glucose } \\
(\mathrm{mmol} / \mathrm{l})\end{array}$ & $7.9 \pm 0.2$ & $29.4 \pm 1.6^{\mathrm{a}}$ & $8.9 \pm 1.3$ \\
$\mathrm{Na}(\mathrm{mEq} / \mathrm{l})$ & $141.0 \pm 0.7$ & $132.0 \pm 0.8^{\mathrm{a}}$ & $140.0 \pm 0.6$ \\
$\begin{array}{l}\text { Total protein }(\mathrm{g} / \mathrm{dl}) \\
\begin{array}{l}\text { Plasma Osm } \\
\left(\mathrm{mOsm} / \mathrm{kg} \mathrm{H}_{2} \mathrm{O}\right)\end{array}\end{array}$ & $5.8 \pm 0.1$ & $5.6 \pm 0.1$ & $6.0 \pm 0.1$ \\
\hline
\end{tabular}

Values are mean $\pm \mathrm{SEM} ; n=6$ rats per group. ${ }^{\mathrm{a}} p<0.01$, vs control

STZ-treatment were statistically analysed using one-way fractional ANOVA followed by Bonferroni-type adjustment for multiple comparisons. The data obtained from in situ hybridization histochemistry were also analysed using one-way fractional ANOVA followed by Bonferroni-type adjustment for multiple comparisons. Statistical significance was established at the less than $p<0.05$ level.

\section{Results}

Effects of STZ-induced diabetes and insulin treatment on $n N O S$ and $A V P$ gene expression. Body weights increased from $149 \pm 1.4$ to $246 \pm 8.6 \mathrm{~g}$ in diabetic rats $(n=6)$, from $150 \pm 3.0$ to $300 \pm 13 \mathrm{~g}$ in diabetic rats treated with insulin $(n=6)$ and from $146 \pm 2.1$ to $373 \pm 9.0 \mathrm{~g}$ in control rats $(n=6)$. The plasma concentrations of glucose, sodium, total protein and osmolality are shown in Table 1. Plasma glucose and osmolality were significantly increased in diabetic rats. Plasma concentration of sodium was significantly decreased in diabetic rats. Total protein in plasma did not change in diabetic and insulin-treated rats. Treatment with insulin for 1 week induced a reduction in plasma concentrations of glucose, sodium and osmolality within the normal range in diabetic rats. In situ hybridization histochemistry revealed that diabetes for 4 weeks induced a significant increase in nNOS transcripts in the PVN $(175 \pm 8.5 \%$ of controls $)$ and SON (201 $\pm 12 \%$ of controls) ( $n=6$ in each case, $p<0.01)$ (Fig. $1 \mathrm{~A}$ and $\mathrm{B}$ ). This increase in expression of the nNOS gene in the PVN and SON in diabetic rats was reversed by insulin treatment to $110 \pm 5.2 \%$ of control in the PVN and $119 \pm 8.1 \%$ of control in the SON ( $n=6$ in each case) (Fig. 1 A and B). The absolute values of the control levels of nNOS gene expression were $3284 \mathrm{kBq} / \mathrm{g}$ in the PVN and $4446 \mathrm{kBq} /$ in the SON. Microscopic examination revealed that the number of cells expressing the nNOS gene and associated signals increased in the PVN and SON of diabetic rats (Fig. 2). Cells that expressed the nNOS gene were primarily observed in the magnocellular and the medial parvocellular parts of the PVN and throughout the SON. In situ hybridization histochemistry also re- 

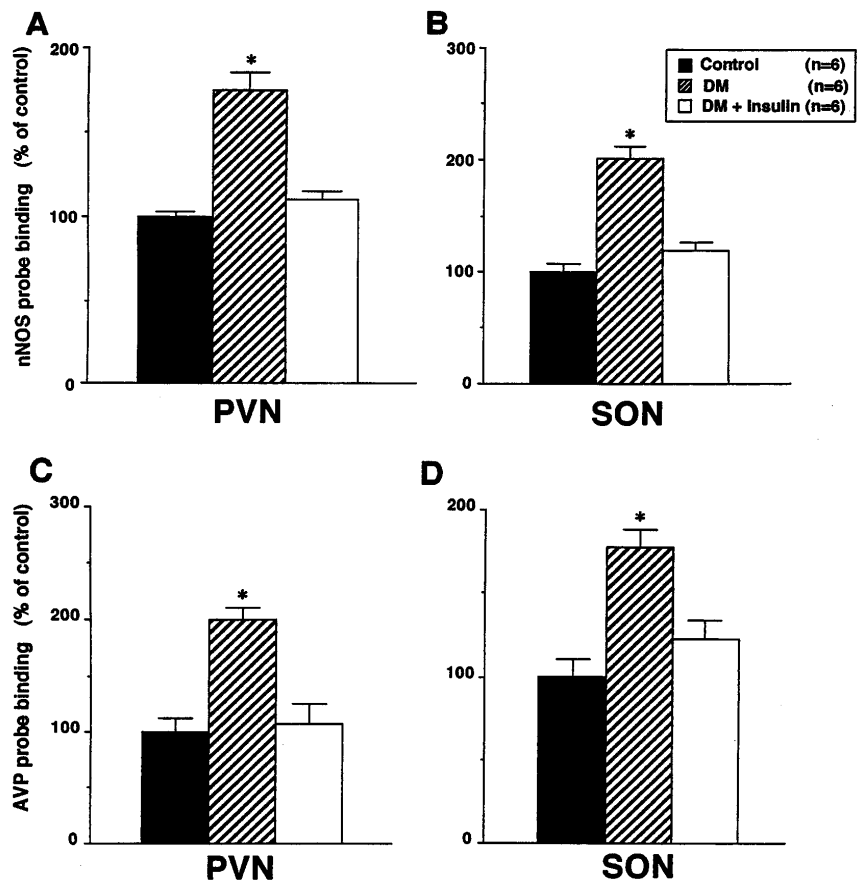

D
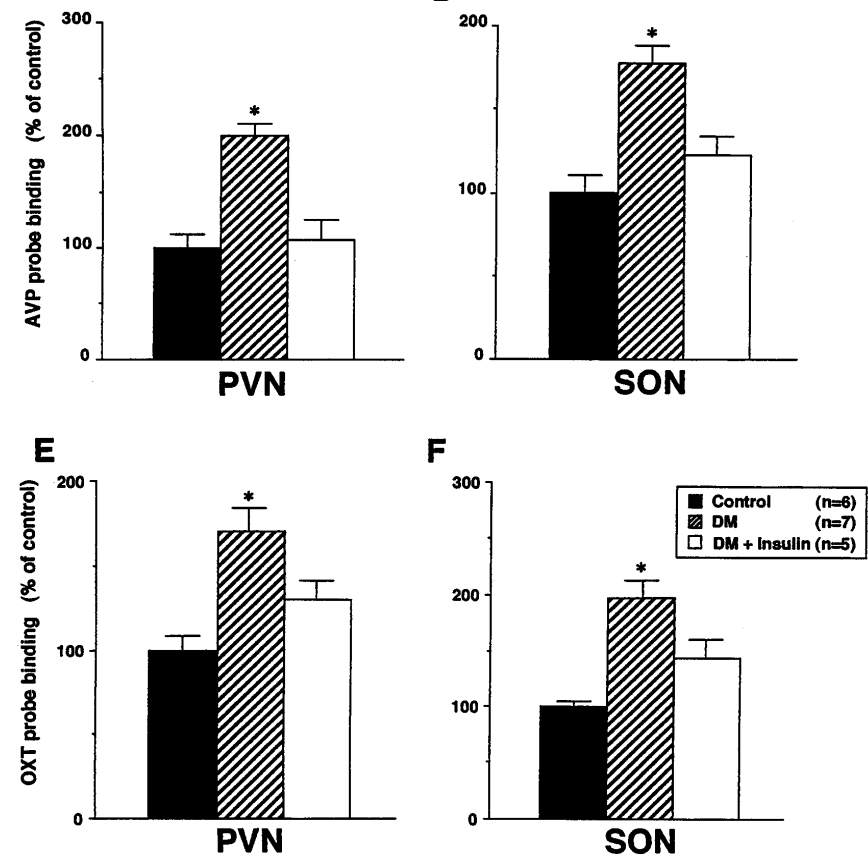

Fig. 1. A-F. Effects of STZ-treatment on nNOS (A, B), AVP $(\mathbf{C}, \mathbf{D})$ and oxytocin $(\mathbf{E}, \mathbf{F})$ transcript prevalence in the PVN and SON. Values represent mean \pm SEM, $n=5-7$ rats; $* p<0.01$ compared to control (one-way fractional ANOVA followed by Bonferroni-type adjustment for multiple comparisons). Panels 'A-D' were obtained from the same groups. Panels ' $\mathbf{E}$ ' and ' $\mathbf{F}$ ' were obtained from different experimental groups

vealed that diabetes for 4 weeks induced a significant increase in AVP transcripts in the PVN $(200 \pm 9.3 \%$ of control) and SON (178 $\pm 11 \%$ of control) $(n=6$ in each case, $p<0.01$ ) (Fig. $1 \mathrm{C}$ and D). This increase in expression of the AVP gene in the PVN and SON in diabetic rats was also reversed by insulin treatment to $108 \pm 16 \%$ of control in the PVN and $123 \pm 11 \%$ of control in the SON ( $n=6$ in each case) (Fig. $1 \mathrm{C}$ and D). The absolute values of the control levels of AVP gene expression were $741682 \mathrm{kBq} / \mathrm{g}$ in the PVN and $712378 \mathrm{kBq} / \mathrm{g}$ in the SON. Representative autoradiography hybridized to the specific probe complementary to AVP mRNA in the magnocellular parts of the PVN and SON of control, diabetic and insulin-treated diabetic rats are shown in Figure $3 \mathrm{~A}-\mathrm{a}-\mathrm{c}$ and $\mathrm{B}-\mathrm{a}-\mathrm{c}$.
Eight rats did not develop hyperglycaemia after i.p. administration of STZ. Two of them were treated with insulin for 1 week. They were similarly examined simultaneously with the diabetic and control rats. Their results obtained from six non-diabetic rats were not significantly different from those of the control rats. Although the two rats treated with insulin became hypoglycaemic ( 2.8 and $3.4 \mathrm{mmol} / \mathrm{l}$ in plasma), expression of the nNOS gene did not decrease $(115 \%$ of the control in the PVN and $124 \%$ of the control in the SON).

Effects of STZ-induced diabetes and insulin-treatment on $n N O S$ and oxytocin gene expression. The body weights changed from $84 \pm 2.6$ to $236 \pm 12 \mathrm{~g}$ in diabetic rats $(n=6)$ and from $80 \pm 1.7$ to $298 \pm 9.4 \mathrm{~g}$ in control rats $(n=6) 4$ weeks after i.p. administration of STZ or saline. The plasma concentration of glucose was significantly higher in diabetic rats and than in control rats at the end of 4 weeks after i.p. administration of STZ or $0.9 \% \mathrm{NaCl}$. The plasma concentrations of glucose, sodium and osmolality were similar to the results obtained from the first experiment (Table 1). Plasma glucose and osmolality were significantly increased in diabetic rats. Plasma concentration of sodium was significantly decreased in diabetic rats. Treatment with insulin for 1 week induced a reduction in plasma concentrations of glucose, sodium and osmolality within the normal range in diabetic rats. In situ hybridization histochemistry again revealed that diabetes for 4 weeks induced a significant increase in nNOS transcripts in the PVN $(157 \pm 12 \%$ of control) and SON $(191 \pm 8.9 \%$ of control) $(n=6$; control rats, $n=7$; diabetic rats, $p<0.01)$. This increase in expression of the nNOS gene in the PVN and SON in diabetic rats was reversed by insulin treatment to $101 \pm 3.6 \%$ of control in the PVN and $131 \pm 14 \%$ of control in the SON ( $n=5$; insulin-treated diabetic rats). The absolute values of the control level of nNOS gene expression were $15707 \mathrm{kBq} / \mathrm{g}$ in the PVN and $13351 \mathrm{kBq} / \mathrm{g}$ in the SON. In situ hybridization histochemistry also revealed that diabetes for 4 weeks induced a significant increase in oxytocin transcripts in the PVN $(170 \pm 13 \%$ of control) and SON (198 $\pm 15 \%$ of control) $(n=6$ in control rats and $n=7$ in diabetic rats, $p<0.01$ ) (Fig. 1E and F). This increase in expression of the oxytocin gene in the PVN and SON in diabetic rats was reversed by insulin treatment to $130 \pm 11 \%$ of control in the PVN and $143 \pm 16 \%$ of control in the SON ( $n=5$ in insulin-treated diabetic rats) (Fig. 1E and $\mathrm{F}$ ). The absolute measurements of control level of oxytocin gene expression were $517050 \mathrm{kBq} / \mathrm{g}$ in the PVN and $351470 \mathrm{kBq} / \mathrm{g}$ in the SON. Representative autoradiography hybridized to the specific probe complementary to oxytocin mRNA in the magnocellular parts of the PVN and SON of control, diabetic and insulin-treated diabetic rats are shown in Figure $3 \mathrm{~A}-\mathrm{d}-\mathrm{f}$ and B-d-f. 

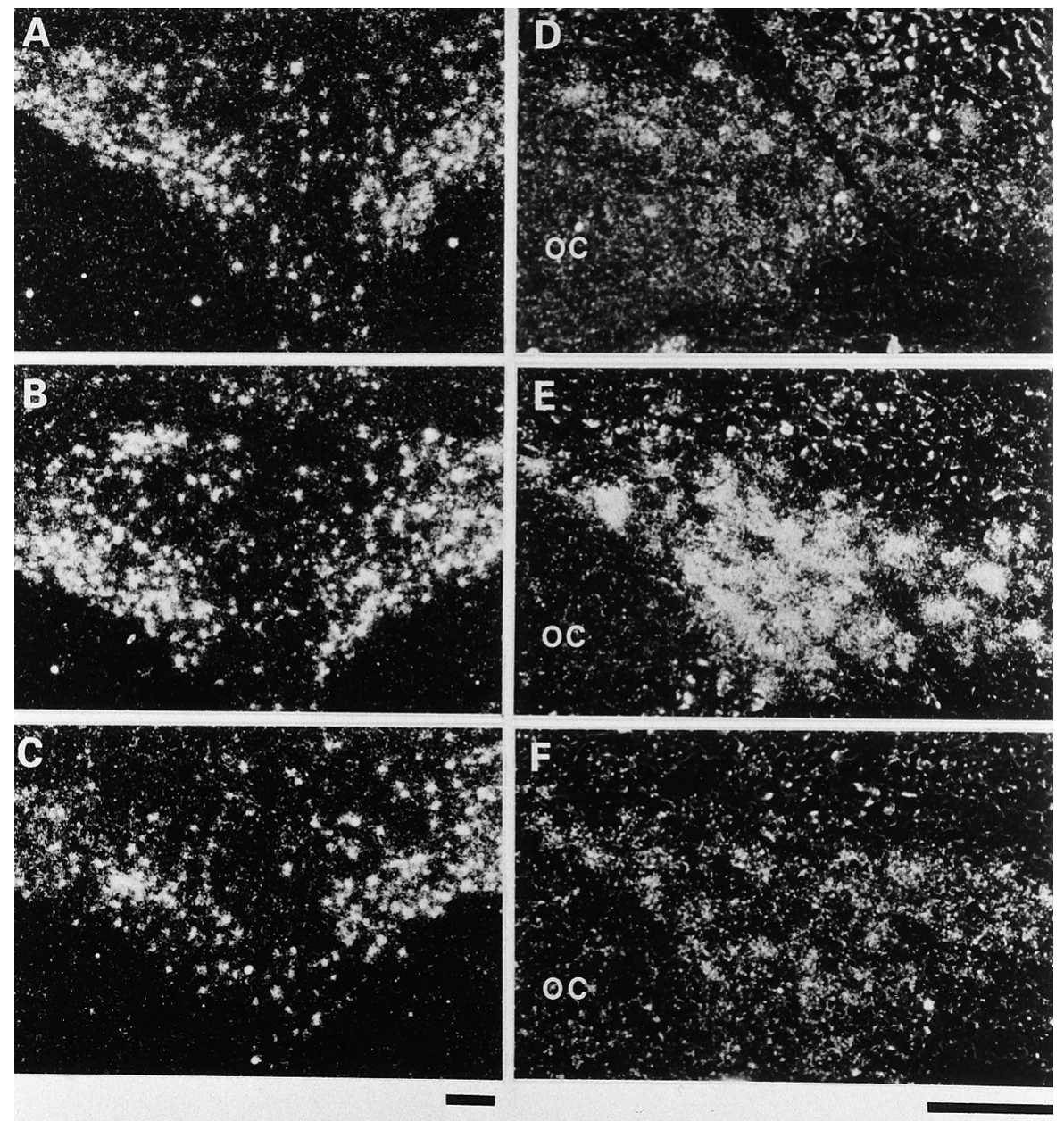

Fig. 2. A-F. Dark field photomicrographs of emulsion-dipped tissue hybridized to a ${ }^{35} \mathrm{~S}$-labelled oligodeoxynucleotide probe complementary to nNOS mRNA in the PVN (A-C) and SON (D-F). A and $\mathbf{D}$ show sections from control rats; $\mathbf{B}$ and $\mathbf{E}$ from STZ-induced diabetic rats; $\mathbf{C}$ and $\mathbf{F}$ from diabetic rats with insulin treatment. Scale bars are $100 \mu \mathrm{m}$ OC, Optic chiasma

In this experiment eight rats did not develop hyperglycaemia after i.p. administration of STZ. They were similarly examined simultaneously with the diabetic and control rats. Their results were not significantly different from those of the control rats.

Effects of insulin treatment on nNOS gene expression in normal rats. The plasma concentrations of glucose in control $(n=6)$, fasted for $24 \mathrm{~h}(n=6)$ and insulintreated and fasted rats $(n=4)$ were $5.6 \pm 0.2,3.3 \pm 0.2$ and $3.7 \pm 0.2 \mathrm{mmol} / \mathrm{l}$, respectively. Expression of the nNOS gene in the PVN and SON in insulin-treated and fasted rats was significantly increased to $150 \pm 4.6 \%$ of control in the PVN and $155 \pm 16 \%$ of control in the SON, respectively. The expression of nNOS gene in the PVN and SON in fasted rats without insulin treatment were similar to that in control.

Effects of phlorizin-treatment on nNOS gene expression in STZ-induced diabetic rats. The body weights changed from $122 \pm 1.5$ to $264 \pm 6.1 \mathrm{~g}$ in control $(n=6)$, from $127 \pm 1.4$ to $246 \pm 6.1 \mathrm{~g}$ in Group I $(n=6)$, from $124 \pm 2.0$ to $241 \pm 3.9 \mathrm{~g}$ in Group II $(n=6)$, from $123 \pm 3.1$ to $160 \pm 9.0 \mathrm{~g}$ in Group III $(n=7)$ and from $122 \pm 1.4$ to $152 \pm 8.9 \mathrm{~g}$ in Group IV $(n=5)$. The plasma concentrations of glucose, sodium and osmolality are shown in Table 2 . The plasma concentrations of glucose and sodium are normalized in Group IV. Plasma osmolality was decreased in Group IV, but significantly higher than that in control. The expression of nNOS gene in the PVN and SON did not change significantly in control, Group I and Group II (Fig. 4). The increase of nNOS gene in the PVN and SON in Group III was reversed by phlorizin treatment and diet from $178 \pm 5.9 \%$ to $109 \pm 6.9 \%$ of control in the PVN and from $225 \pm 6.3 \%$ to $139 \pm 5.5 \%$ of control in the SON (Fig.4). The absolute values of the control levels of nNOS gene expression were $1169 \mathrm{kBq} / \mathrm{g}$ in the PVN and $8785 \mathrm{kBq} / \mathrm{g}$ in the SON.

Effects of STZ-induced diabetes on NADPH-diaphorase staining. As shown in Figure 5, NADPH-diaphorase staining revealed that the cell bodies and 

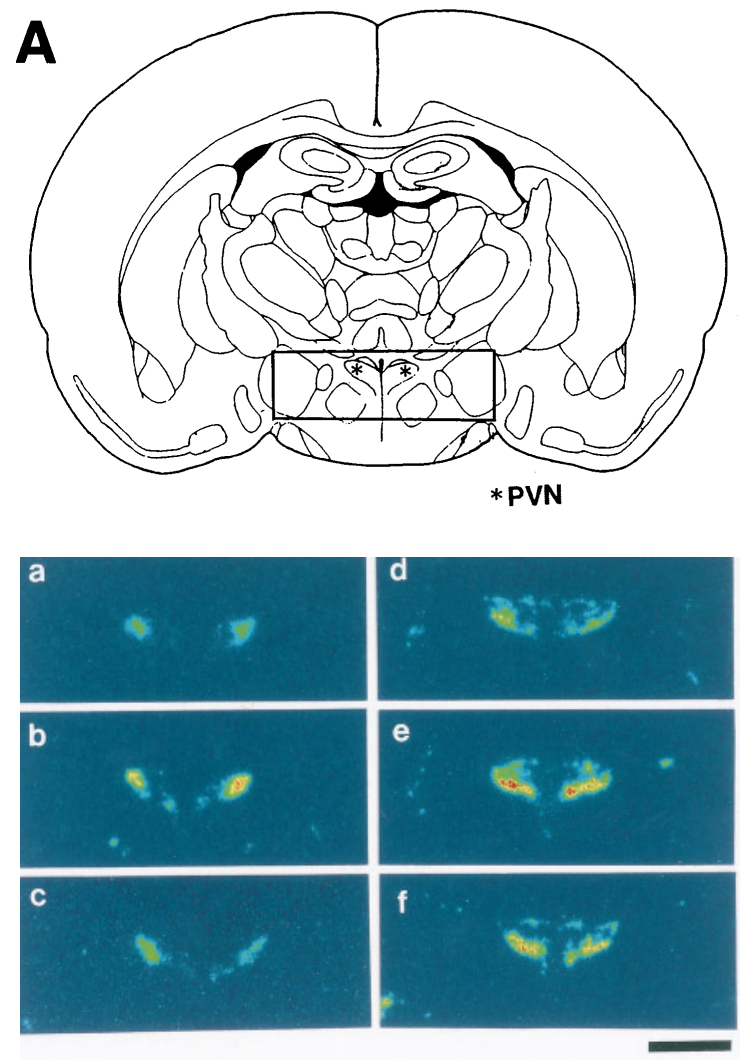

Fig.3.A,B. Representative computer-generated colour images of autoradiograms of tissue hybridized to a ${ }^{35} \mathrm{~S}$-labelled oligodeoxynucleotide probe complementary to AVP mRNA (A a-c and $\mathbf{B} \mathrm{a}-\mathrm{c}$ ) and oxytocin mRNA ( $\mathbf{A} \mathrm{d}-\mathrm{f}$ and $\mathbf{B} \mathrm{d}-\mathrm{f}$ ) in the PVN (A) and SON (B). 'Red' is most intense signal and 'dark blue' is least intense signal. The density of autoradiographs was measured by comparison with simultaneously exposed $\left[{ }^{14} \mathrm{C}\right]$ micro-scale. Panels ' $\mathbf{A}$ a,d' and ' $\mathbf{B}$ a,d' are sections from control rats; panels ' $\mathbf{A}$ b,e' and ' $\mathbf{B}$ b,e' from diabetic rats; panels ' $\mathbf{A} \mathrm{c}$, f' and ' $\mathbf{B} \mathrm{c}, \mathrm{f}$ ' from diabetic rats with insulin treatment. The cartoons illustrate the limits of autoradiographs. Scale bars are $1 \mathrm{~mm}$

fibres in the PVN and SON were more densely stained in diabetic rats compared to control rats. NADPH-diaphorase staining appeared to be located in the dorsal part more than the ventral part of the SON. In the PVN, the distribution of NADPH-diaphorase stained cell was observed in the posterior magnocellular and the medial parvocellular regions. This increase in NADPH-diaphorase staining supports the notion that NOS activity in the PVN and $\mathrm{SON}$ increases in diabetic rats.

All experiments were undertaken independently. The results obtained from five independent experiments were consistent.
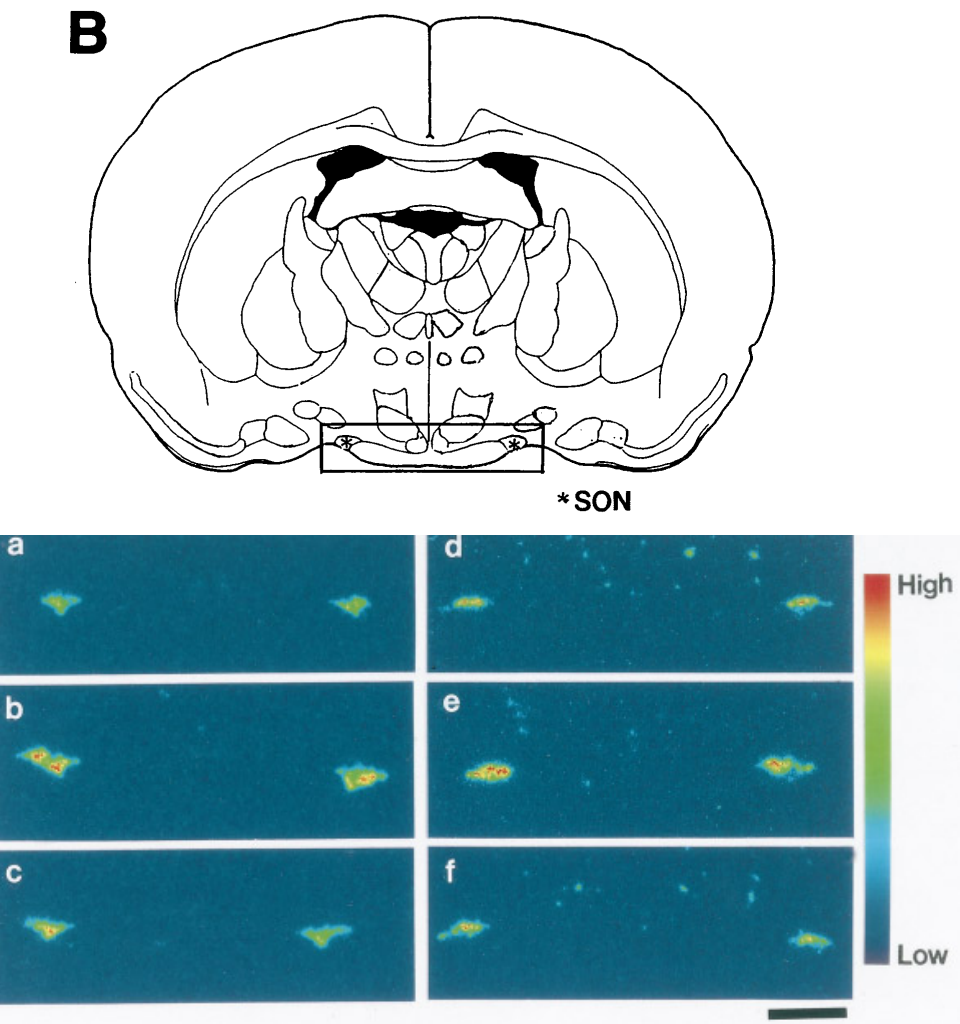

\section{Discussion}

The present study has provided the first evidence of significant increases in the expression of nNOS gene as well as the AVP and oxytocin genes in the PVN and SON in STZ-induced diabetic rats. The upregulation of the nNOS gene in the PVN and SON in diabetic rats was suppressed by insulin treatment, indicating that non-specific effects of STZ were excluded. The upregulation of the nNOS gene in the PVN and SON in diabetic rats was also suppressed by normalizing the hyperglycaemia in diabetic rats treated with phlorizin and diet.

In diabetic rats, we observed a significant increase in plasma osmolality compared with control rats. Hyperosmolality caused by dehydration and chronic salt loading increases in the expression of the nNOS gene in the PVN and SON [15-18]. Although hypernatraemia may upregulate nNOS gene expression in the PVN and SON in diabetic rats, the plasma concentration of sodium significantly decreased in these rats. The reduction in plasma sodium may be the result of the increased excretion of sodium in the urine of the diabetic rats. As total protein in plasma did not change in the diabetic and insulin-treated diabetic rats, hypovolaemia may not have occurred in those rats. Therefore, osmotic stimulation may explain the upregulation of nNOS gene expression in the PVN and SON observed in the STZ-induced diabetic rats. Recent studies have demonstrated that NO in the hypothalamus may modulate secretion of AVP [17, 21, 


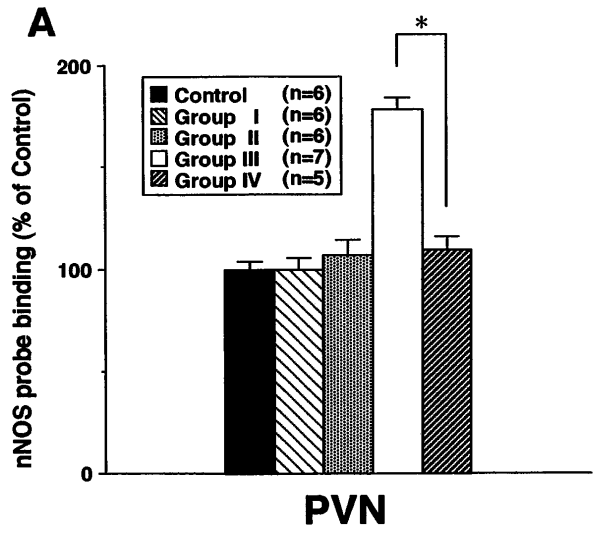

Fig. 4. A, B. Effect of phlorizin treatment and diet on nNOS transcript prevalence in the PVN and SON. Values represent mean \pm SEM, $n=5-7$ rats; $* p<0.01$ compared to control (one-way fractional ANOVA followed by Benferroni-type adjustment for multiple comparisons). $\mathbf{A}$ and $\mathbf{B}$ were obtained from the same groups. Group I: phlorizin $(0.4 \mathrm{~g} / \mathrm{kg}$ body weight/day) was administered s.c. every $8 \mathrm{~h}$ for 12 days in normal rats $(n=6)$, Group II: food was restricted for one and one half days before the decapitation in normal rats $(n=6)$, Group III: STZ-induced diabetic rats $(n=7)$, Group IV: phlorizin $(0.4 \mathrm{~g} / \mathrm{kg}$ body weight/day) was administered s.c. every $8 \mathrm{~h}$ for 12 days, and food was restricted for one and one half days before the decapitation in STZ-induced diabetic rats $(n=5)$

22] and oxytocin [21-23]. Some anatomical studies have demonstrated that NADPH-diaphorase activity co-exists with AVP- and oxytocin immunoreactivity $[26,27]$. They also showed that the co-existence of NADPH-diaphorase staining and oxytocin immunoreactivity is more predominant than that of NADPH-diaphorase staining and AVP immunoreactivity. In the present study, the distribution of NADPH-diaphorase staining in the PVN and SON is consistent with previous studies [26,27]. The synthesis of hypothalamic AVP and oxytocin increases in diabetic rats [6] as confirmed by our result that the expression of AVP and oxytocin genes in the PVN and $\mathrm{SON}$ is upregulated in diabetic rats.

The sensitivity of the AVP response to osmotic stimuli has been shown to be significantly reduced in

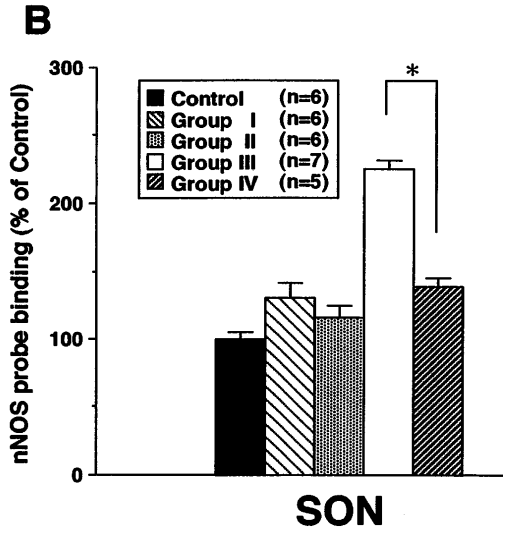

diabetic patients [28] and STZ-induced diabetic rats [29]. One possible reason is that NO suppresses the excitatory input to the PVN and SON and causes a reduction in sensitivity to osmotic stimuli in the diabetic state, because NO in the PVN and SON tonically inhibit secretion of AVP and oxytocin [21, 22]. Furthermore, diabetes is known to induce changes in the noradreanline and adrenaline concentrations of the various brain regions, including the hypothalamus [1, 2]. These changes may also be influenced by excessive NO in the PVN and SON. These possibilities require further examination.

Chiodera et al. [20] demonstrated that the increase in plasma AVP and oxytocin response to insulin-induced hypoglycaemia in men is enhanced by NOS inhibitor, N, G-nitro-L-arginine methyl ester (LNAME). They suggested that NO may have an inhibitory role in the control of AVP and oxytocin responses to hypoglycaemia. Although marked hyperglycaemia was observed in the diabetic rats, whether NO has a physiological role in the control of AVP and oxytocin responses to hyperglycaemia remains unknown. As phlorizin, a continuous inhibitor of renal tubular reabsorption of glucose, is a useful drug with which to distinguish between the roles of hyperglycaemia and hypoinsulinaemia in the regulation of nNOS gene expression in the PVN and SON, we made phlorizin-treated rats according to the previously published protocol [25]. The phlorizin-treated rats with diet showed the reduction of nNOS gene in the PVN and SON by normalizing the hyperglyca-

Table 2. Plasma glucose, sodium and osmolality in plasma after 2 weeks after administration of streptozotocin and phlorizin treatment

\begin{tabular}{|c|c|c|c|c|c|}
\hline & Control & Group I & Group II & Group III & Group IV \\
\hline Plasma glucose $(\mathrm{mmol} / \mathrm{l})$ & $8.3 \pm 0.3$ & $8.5 \pm 0.3$ & $7.4 \pm 2.8$ & $29.7 \pm 1.9^{\mathrm{b}}$ & $8.2 \pm 0.9$ \\
\hline $\mathrm{Na}(\mathrm{mEq} / \mathrm{l})$ & $141 \pm 1.0$ & $142 \pm 0.4$ & $142 \pm 0.7$ & $128 \pm 1.5^{\mathrm{b}}$ & $142 \pm 1.2$ \\
\hline Plasma Osm $\left(\mathrm{mOsm} / \mathrm{kg} \mathrm{H}_{2} \mathrm{O}\right)$ & $297 \pm 2.6$ & $292 \pm 3.7$ & $295 \pm 2.8$ & $315 \pm 2.1^{b}$ & $307 \pm 2.2^{\mathrm{a}}$ \\
\hline
\end{tabular}

Group I: phlorizin $(0.4 \mathrm{~g} / \mathrm{kg}$ body weight/day) administered s.c. every $8 \mathrm{~h}$ for 12 days in normal rats $(n=6)$, Group II: food was restricted for one and one half days before the decapitation in normal rats $(n=6)$, Group III: STZ-induced diabetic rats $(n=7)$, Group IV: phlorizin $(0.4 \mathrm{~g} / \mathrm{kg}$ body weight/day) administered s.c. every $8 \mathrm{~h}$ for 12 days, and food was restricted for one and one half days before the decapitation in STZ-induced diabetic rats $(n=5)$. Values are the mean \pm SEM; $n=5-7$ rats per group. ${ }^{\mathrm{a}} p<0.05,{ }^{\mathrm{b}} p<0.01$ vs control 

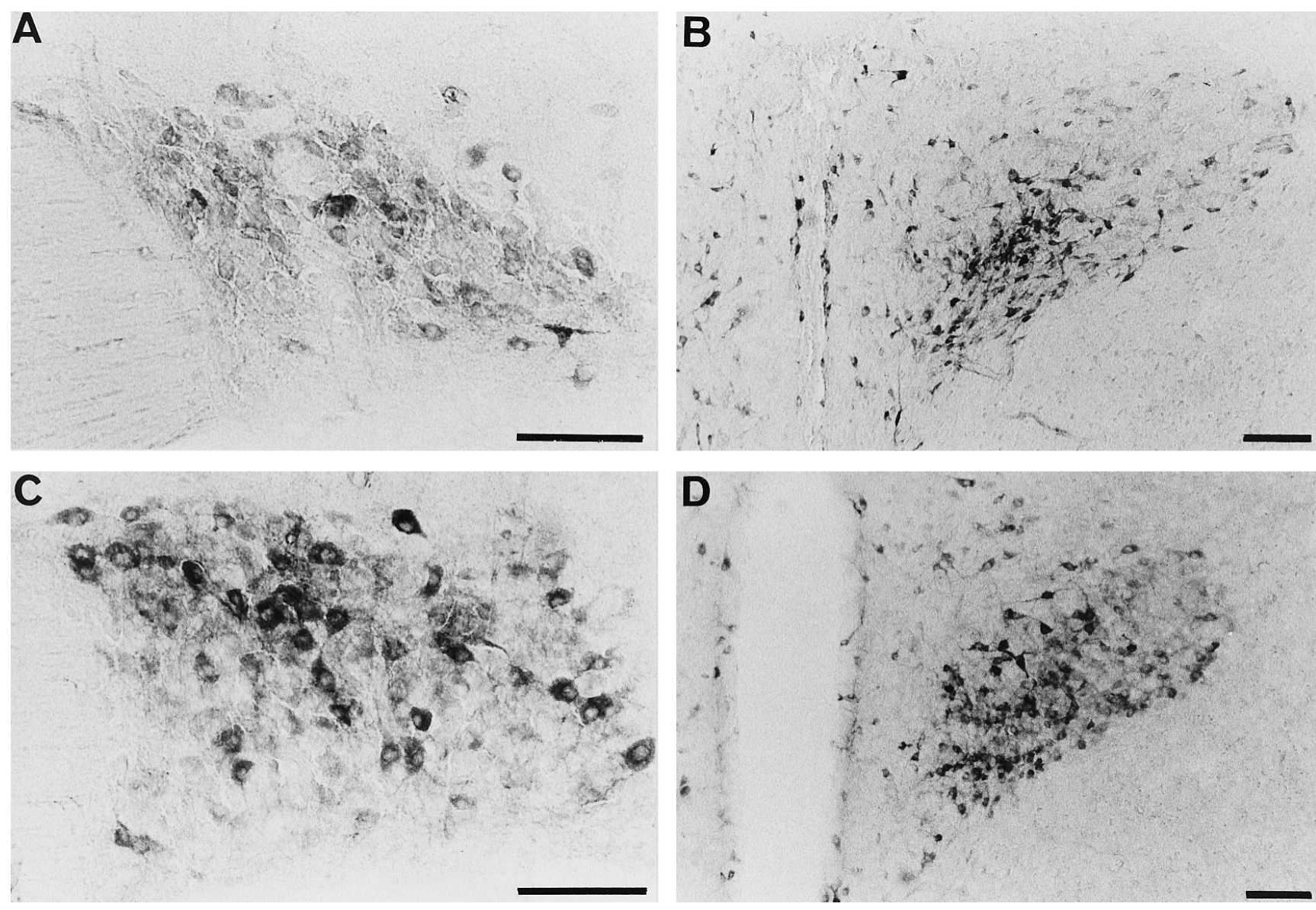

Fig. 5. A-D. Representative NADPH-diaphorase staining in the SON and PVN. A and $\mathbf{B}$ are sections from control rats; $\mathbf{C}$ and $\mathbf{D}$ from diabetic rats. Density of NADPH-diaphorase staining increased in the SON (C) and PVN (D) of diabetic rats compared with the SON (A) and PVN (B) of controls. Scale bars are $100 \mu \mathrm{m}$

emia. The plasma osmolality in these rats decreased, but was significantly higher than control levels. Therefore, hyperglycaemia may be more dominant than plasma hyperosmolality in causing the upregulation of nNOS gene expression in the PVN and SON in the diabetic rats. In addition, we found that expression of the nNOS gene in the PVN and SON did not decrease in STZ-administered non-diabetic rats treated with insulin and significantly increased in normal rats treated with insulin. Therefore, insulin treatment itself probably does not decrease expression of the nNOS gene in the PVN and SON.

Diabetes causes behavioural abnormalities such as hyperphagia and polydipsia. Several studies have demonstrated that diabetes induces changes in the expression of genes coding for feeding-related peptides such as neuropeptide Y (NPY), cholecystokinin and corticotropin-releasing hormone in the hypothalamus [3]. The hypothalamic contents of NPY $[4,5]$ and prodynorphin-derived peptides in the hypothala-

mus [7] have been shown to increase in diabetic rats. As it has been demonstrated that NO may modulate hypothalamic NPY-induced feeding [8], the central serotonergic system related to feeding [10], an excess of NO may be involved in the central mechanism of hyperphagia in diabetes. In addition, several previous studies have demonstrated that feeding and metabolic change such as food deprivation $[15,30]$ and hyperor hypothyroidism [31] caused a significant change in the expression of nNOS gene in the hypothalamus, suggesting that NO may be associated with feeding control and metabolism.

In conclusion, we have demonstrated that expression of the nNOS gene as well as AVP and oxytocin genes in the PVN and SON increases in diabetic rats, suggesting that hyperglycaemia and plasma hyperosmolality may cause upregulation of these genes in the hypothalamus.

Acknowledgements. We express our appreciation to Ms R. Nishi for her technical assistance. This work was supported in part by Grants-in Aids for Scientific Research (A), (B), Nos. 08457022 and 07507004 for H. Y., Grants-in-Aid for Encouragement of Young Scientists, No.09770046 for Y.U. from the Ministry of Education, Science, Sports and Culture, Japan, Special Grant by the Ministry of Labor for 'Occupational Health Studies', a grant provided by the Ichiro Kanehara Foundation, a grant provided by the Uehara Memorial Foundation and a research grant from the Ministry of Health and Welfare. 


\section{References}

1. Ramakrishnan R, Namasivayam A (1995) Norepinephrine and epinephrine levels in the brain of alloxan diabetic rats. Brain Res 186: 200-202

2. Bitar MS, Koulu M, Linnoila M (1987) Diabetes-induced changes in monoamine concentrations of rat hypothalamic nuclei. Brain Res 409: 236-242

3. Sipols AJ, Baskin DG, Schwartz MW (1995) Effect of intracerebroventricular insulin infusion on diabetic hyperphagia and hypothalamic neuropeptide gene expression. Diabetes 44: 147-151

4. Abe M, Saito M, Ikeda H, Shimazu T (1991) Increased neuropeptide $Y$ content in the arcuato-paraventricular hypothalamic neuronal system in both insulin-dependent and non-insulin-dependent diabetic rats. Brain Res 539: 223-227

5. Lambert PD, Wilding JPH, Turton MD, Ghatei MA, Bloom SR (1994) Effect of food deprivation and streptozotocin-induced diabetes on hypothalamic neuropeptide $\mathrm{Y}$ release as measured by a radioimmunoassay-linked microdialysis procedure. Brain Res 656: 135-140

6. Fernstrom JD, Fernstrom MH, Kwok RPS (1990) In vivo somatostatin, vasopressin, and oxytocin synthesis in diabetic rat hypothalamus. Am J Physiol 258: E661-E666

7. Berman Y, Devi L, Carr KD (1995) Effects of streptozotocin-induced diabetes on prodynorphin-derived peptides in rat brain regions. Brain Res 685: 129-134

8. Morley JE, Flood JF (1992) Competitive antagonism of nitric oxide synthase causes weight loss in mice. Life Sci 51: 1285-1289

9. Morley JE, Flood JF (1991) Evidence that nitric oxide modulates food intake in mice. Life Sci 49: 707-711

10. Squadrito F, Calapai G, Altavilla D et al. (1994) Food deprivation increases brain nitric oxide synthase and depresses brain serotonin levels in rats. Neuropharmacology 33: 83-86

11. Choi Y-H, Furuse M, Okumura J, Denbow DM (1994) Nitric oxide controls feeding behaviour in the chicken. Brain Res 654: 163-166

12. Squadrito F, Calapai G, Cucinotta D et al. (1993) Anorectic activity of $\mathrm{N}^{\mathrm{G}}$-nitro-L-arginine, an inhibitor of brain nitric oxide synthase, in obese Zucker rats. Eur J Pharmacol 230: $125-128$

13. Calapai G, Squadrito F, Altavilla D et al. (1992) Evidence that nitric oxide modulates drinking behaviour. Neuropharmacology 31: 761-764

14. Calapai G, Mazzaglia G, Cilia M, Zingarelli B, Squadrito F, Caputi AP (1994) Mediation of nitric oxide formation in the preoptic area of endotoxin and tumour necrosis factorinduced inhibition of water intake in the rat. Br J Pharmacol 111: 1328-1332

15. O'Shea RD, Gundlach AL (1996) Food or water deprivation modulate nitric oxide synthase (NOS) activity and gene expression in rat hypothalamic neurones: correlation with neurosecretory activity? J Neuroendocrinol 8: 417-425

16. Ueta Y, Levy A, Chowdrey HS, Lightman SL (1995) Water deprivation in the rat induces nitric oxide synthase (NOS) gene expression in the hypothalamic paraventricular and supraoptic nuclei. Neurosci Res 23: 317-319
17. Kadowaki K, Kishimoto J, Leng G, Emson PC (1994) Upregulation of nitric oxide synthase (NOS) gene expression together with NOS activity in the rat hypothalamo-hypophysial system after chronic salt loading: evidence of a neuromodulatory role of nitric oxide in arginine vasopressin and oxytocin secretion. Endocrinology 134: 1011-1017

18. Villar MJ, Ceccatelli S, Ronnqvist M, Hökfelt T (1994) Nitric oxide synthase increases in hypothalamic magnocellular neurons after salt loading in the rat. An immunohistochemical and in situ hybridization study. Brain Res 644: 273-281

19. Yasin S, Costa A, Trainer P, Windle R, Forsling ML, Grossman A (1993) Nitric oxide modulates the release of vasopressin from rat hypothalamic explants. Endocrinology 133: $1466-1470$

20. Chiodera P, Volpi R, Coiro V (1994) Inhibitory control of nitric oxide on the arginine-vasopressin and oxytocin response to hypoglycaemia in normal men. NeuroReport 5: $1822-1824$

21. Kadekaro M, Liu H, Terrell ML, Gestl S, Bui V, SummyLong JY (1997) Role of NO on vasopressin and oxytocin release and blood pressure responses during osmotic stimulation in rats. Am J Physiol 273: R1024-R1030

22. Liu H, Terrell ML, Bui V, Summy-Long JY, Kadekaro M (1997) NO and angiotensin II effects on blood pressure and fluid homeostasis. J Neuroendocrinol 9: 545-552

23. Summy-Long JY, Bui V, Mantz S et al. (1993) Inhibition of nitric oxide synthase preferentially augments release of oxytocin during dehydration. Neurosci Lett 152: 190-193

24. Vokes TP, Aycinena PR, Robertson GL (1987) Effect of insulin on osmoregulation of vasopressin. Am J Physiol 252: E538-E548

25. Begum N, Draznin B (1992) Effect of streptozotocin-induced diabetes on GLUT-4 phosphorylation in rat adipocytes. J Clin Invest 90: 1254-1262

26. Hatakeyama S, Kawai Y, Ueyama T, Senba E (1996) Nitric oxide synthase-containing magnocellular neurons of the rat hypothalamus synthesize oxytocin and vasopressin and express Fos following stress stimuli. J Chem Neuroanat 11: 243-256

27. Miyagawa A, Okamura H, Ibata Y (1994) Coexistence of oxytocin and NADPH-diaphorase in magnocellular neurons of the paraventricular and the supraoptic nuclei of the rat hypothalamus. Neurosci Lett 171: 13-16

28. Iwasaki Y, Kondo K, Murase T, Hasegawa H, Oiso Y (1996) Osmoregulation of plasma vasopressin in diabetes mellitus with sustained hyperglycemia. J Neuroendocrinol 8: 755-760

29. Akaishi T, Homma S (1992) Hypothalamic osmoregulation for vasopressin release in streptozotocin-diabetic rats in vivo and in vitro. Brain Res 569: 86-92

30. Ueta Y, Levy A, Chowdrey HS, Lightman SL (1995) Inhibition of hypothalamic nitric oxide synthase gene expression in the rat paraventricular nucleus by food deprivation is independent of serotonin depletion. J Neuroendocrinol 7: $861-865$

31. Ueta Y, Levy A, Chowdrey HS, Lightman SL (1995) Hypothalamic nitric oxide synthase gene expression is regulated by thyroid hormones. Endocrinology 136: 4182-4187 